\title{
Exercise capacity, Cardiovascular- and Metabolic Risk of German Police officers in an international comparison
}

\author{
Markus Strauß ( $\square$ markus.strauss@uni-wh.de) \\ University of Witten/Herdecke

\section{Peter Foshag} \\ University of Witten/Herdecke: Universitat Witten/Herdecke \\ Ulrich Jehn \\ Universitätsklinikum Münster: Universitatsklinikum Munster

\section{Richard Vollenberg} \\ Universitätsklinikum Münster: Universitatsklinikum Munster

\section{Henning Littwitz} \\ University of Witten/Herdecke: Universitat Witten/Herdecke

\section{Roman Leischik} \\ University of Witten/Herdecke: Universitat Witten/Herdecke
}

\section{Research}

Keywords: police officers, physical fitness, risk factor, cardiovascular risk, metabolic risk

Posted Date: October 2nd, 2020

DOI: https://doi.org/10.21203/rs.3.rs-84144/v1

License: (a) (1) This work is licensed under a Creative Commons Attribution 4.0 International License. Read Full License 


\section{Abstract}

Background: The police force has a mandate to protect citizens and enforce law for public safety. Employment in the police force is recognized as a dangerous occupation and characterized by job-related physical hazards. Therefore, good health and adequate physical condition are necessary. The aim of this study was to determine cardiovascular, cardiorespiratory and metabolic risk parameters of German police officer (POs) in comparison to POs from other nations.

Methods: 55 male police officers from Germany participated in the survey. Anthropometric measurements, cardiovascular and metabolic risk factors and blood parameters were taken. 10-year cardiovascular risk was calculated by using the Framingham Risk Score. The diagnosis of metabolic syndrome was based on the criteria of the International Diabetes Federation. Cardiorespiratory status was assessed by exercise spirometry.

Results: The analyzed group of POs demonstrated a high prevalence of preobesity (BMI: $28.0 \pm 3.2$, waist circumference: $97.8 \pm 12.4 \mathrm{~cm}$ ). $61.8 \%$ of POs showed an increased waist circumference. POs shows elevated cholesterol and triglyceride values and high prevalence of abnormal systolic and diastolic blood pressure. 10year cardiovascular system risk of examined POs were $9.6 \pm 7.4 \%$. The cardiovascular risk profile of our examined German cohort seems to be in the higher range in comparison to international data. $32 \%$ of POs in our study group were diagnosed with metabolic syndrome. Maximal relative oxygen uptake of POs was $34.1 \pm 8.0$ $\mathrm{ml} / \mathrm{kg}^{-1} \cdot \mathrm{min}^{-1}$.

Conclusions: To our knowledge this study was one of the first to assess data on cardiovascular health, metabolic syndrome and cardiorespiratory status of police officers in Germany. The results of our study population demonstrated the high cardiovascular and metabolic risk of German police officers and displaying a decreased cardiorespiratory fitness. The present study results demonstrated the need for implementation of interventions and creating health-promoting concepts like corporate sports activities and nutrition courses to counteract cardiovascular and metabolic risk factors and the subsequent development of cardiovascular and metabolic disease in this occupational group.

\section{Background}

The police force has a mandate to protect citizens and enforce law for public safety. But working as a police officer (PO) is recognized as a dangerous occupation. The working condition include job-related hazards as the threat of bodily injury or death, intense physical stress and unpredictable emergency situations (1). Evidence indicates that the prevalence of traditional risk factors for cardiovascular disease among the police force is high (often higher than the general population) (2). This is demonstrated in high prevalence of typical cardiovascular risk factors, including metabolic syndrome, hypertension, hyperlipidemia, cigarette smoking and sedentary lifestyle (3). It is known that POs in the USA have a high risk of sudden cardiac arrest on duties (4). Reasons for this may be attributed to working conditions of job-related stress, inadequate sleep and unhealthy lifestyle (5).

Studies investigating German POs are limited, even though it is of major medical and socio-economic interest to improve on preventing work related development of disease. This study prospectively examined cardiovascular, cardiorespiratory and metabolic parameters in German POs in order to collect epidemiographic risk parameters associated with this occupational group. After conduction of the study a literature search was performed to 
compare our findings in respect to international data. Our aim was to evaluate discrepancies in cardiovascular and metabolic risk amongst different countries.

\section{Methods}

\subsection{Participants}

Male police officers from Germany, North Rhine-Westphalia, were invited to participate in this study via internet advertisements, social media and local corporate distribution after they responded to an official request. The recruitment of study participants was advertised at workplaces. Participation was voluntary. Inclusion criteria were working in police patrol service by shift work at the federal police force of Germany. A group of 55 male participants was included. The group consisted of male Caucasians with an age range between 18 and 55 years.

Examinations were performed at baseline and at one time at the Sports Medicine Centre in Hagen (Research Sector Prevention, Public Health and Sports Medicine, University Witten/Herdecke) by a trained clinician.

\subsection{Assessment tools and procedures}

A questionnaire was used to collect individual sedentary time at work (hrs), use of tobacco and alcohol, and to calculate the metabolic equivalents (METS) based on Ainsworth et al. (6). Values were assessed for one week. Dynamic sport activities such as jogging, cycling, swimming, soccer, martial arts, and anaerobic exercise are summarized under the term dynamic METS. One MET corresponds to $1 \mathrm{kcal}^{\mathrm{kg}} \mathrm{kg}^{-1} \cdot \mathrm{h}^{-1}$.

The measurement of blood pressure was performed in a supine position with calibrated standard blood pressure cuffs. For the classification of blood pressure the ESH/ESC guidelines 2018 for management of hypertension were used (systolic blood pressure $\geq 140 \mathrm{mmHg}$ Hypertension Grade I $\geq 160 \mathrm{mmHg}$ Grade II and $\geq 180 \mathrm{mmHg}$ Grade III) (7). Resting heart rate was measured by a 12-channel-ECG. Waist circumference was measured at the end of expiration in a standing position in the centre of the lower edge of the ribs and the upper edge of the iliac crest.

Participants were asked to fast (refrain from eating and drinking for 4 to 6 hours prior to the examination) before measuring body weight and having blood examinations in the morning. Body weight and body composition were determined using the Tanita BC-418MA segmental body composition analyser (8). For measuring body weight, body composition and body height, participants were instructed to wear only comfortable shorts with no other clothing or shoes. Blood serum parameters that were analysed included: Total cholesterol, high-density lipoprotein (HDL), low-density lipoprotein (LDL), triglyceride, glycated haemoglobin (HbA1c), C-reactive protein (CRP) and lipoprotein (a). Lipoprotein (a) was measured by our laboratory (Immun - Essay La Roche).

The Framingham score was used to calculate cardiovascular risk scores, based on observations and data from the Framingham Heart Study (9). Specifically, in our investigations we applied the 10-year Cardiovascular Disease Risk Score Calculator based on the Framingham-Study (10). The following parameters were measured to calculate cardiovascular risk: age, diabetes, smoking, treated and untreated systolic blood pressure, total cholesterol, HDL levels and BMI.

The classification used to identify individuals with metabolic syndrome was based on the criteria of the International Diabetes Federation (IDF) in 2005 (11). The definition focusses on four entities: obesity, 
dyslipidaemia, hypertension and insulin resistance. For diagnosis, obesity must be present, as well as two other criteria. The main criterion of the IDF definition, central obesity, can be assessed by waist circumference or by BMI. The reference value of waist circumference was $94 \mathrm{~cm}$.

Spiroergometry was performed in following manner (12-14): After successful gas and volume calibration a stress test was conducted beginning at 50 watts and continuously increasing by 25 watts every $2 \mathrm{~min}$ (ramp test). The test ended when the subject could no longer maintain the predefined cadence of $80 / \mathrm{min}$ or if the subject was subjectively exhausted and there was no further increase in $\mathrm{VO}_{2 \max }$ after $20 \mathrm{sec}$. The spiroergometric analyses were conducted as previously described $(13,14)$. The ventilator Aerobic threshold (AT) was defined as the first non-linear increase in the ventilatory equivalent for oxygen without simultaneous increase of the ventilatory equivalent for $\mathrm{CO} 2$. The respiratory compensation point (RCP) was defined as the simultaneous non-linear increase of both ventilatory equivalents according to previously described recommendations $(13,14)$.

\subsection{Statistical Analysis}

For statistical analysis, Stata / IC 13.1 for Windows was used. The anthropometric parameters, clinical characteristics, physical activity and cardiorespiratory fitness parameters were described using the number of participants, means, standard deviations and medians. Categorical characteristics were displayed by specifying absolute and relative frequency. Comparison of the study data with other study results was completed by using means and standard deviations.

\section{Results}

\subsection{Study Population and Basic Characteristics}

In this prospective study all 55 consecutively recruited male participants were included in the study. The participating POs were between 18 and 55 years old. The mean age was $45.3 \pm 7.8$ years (Table 1 ). The POs had $25.2 \pm 8.4$ years of professional experience varying between 5 and 41 years. The corporate sports activity of all participants was $0.58 \pm 0.93 \mathrm{hrs} /$ week, the whole sports activity was $4.83 \pm 4.29 \mathrm{hrs} /$ week. Leisure time activity with vigorous physical activities was $2838 \pm 2872 \mathrm{METs}$ /week. Strength training, soccer, jogging, swimming, and cycling were considered vigorous physical activities. 
Table 1

Basic characteristics of the study population.

\begin{tabular}{|lllll|}
\hline \multicolumn{5}{|c|}{ Police officer } \\
\hline & $\mathrm{n}$ & Mean & SD & Median \\
\hline Age (years) & 55 & 45.3 & 7.8 & 45.0 \\
\hline Weight $(\mathrm{kg})$ & 55 & 93.6 & 13.2 & 91.3 \\
\hline Height $(\mathrm{cm})$ & 55 & 182.8 & 6.8 & 181.0 \\
\hline BMl (kg/m $\left.{ }^{2}\right)$ & 55 & 28.0 & 3.2 & 27.4 \\
\hline BSA by Mosteller & 55 & 2.18 & 0.18 & 2.14 \\
\hline Muscle mass (kg) & 55 & 69.7 & 7.8 & 69.7 \\
\hline Body fat (\%) & 55 & 21.4 & 5.6 & 22.2 \\
\hline Sport activity (hrs/week) & 55 & 4.83 & 4.29 & 3.00 \\
\hline Company sports activity (hrs/week) & 55 & 0.58 & 0.93 & 0.00 \\
\hline
\end{tabular}

\subsection{Cardiovascular Risk}

\subsubsection{Cardiovascular Risk Factors}

POs were slightly above the upper limit of the normal range of $25 \mathrm{~kg} / \mathrm{m}^{2}(\mathrm{BMI})$, thus could be assigned to the preobese/overweight range. POs consumed an average of 2.52 cigarettes per day. In total, $18.2 \%$ of the POs $(n=10)$ consumed nicotine. $76.3 \%$ of the POs had a normal systolic blood pressure (RR $\leq 139 \mathrm{mmHg}$ ). The remaining participants $(23.6 \%)$ had a raised systolic blood pressure at rest $(R R>140 \mathrm{mmHg})$. Diastolic elevated blood pressure values ( $R R \geq 90 \mathrm{mmHg}$ ) were measured in $52,2 \%$ of all participants. The highest systolic blood pressure at rest was $\mathrm{RR}=170 \mathrm{mmHg}$. Representation of blood pressure as seen in our study group is shown in Table 2. The mean resting heart rate value was $68.9 \pm 11.4$ beats per minute.

POs showed raised total cholesterol $(205.9 \pm 40.4)$ and triglyceride $(185.1 \pm 145.4)$ values. The parameters HDL, $\mathrm{LDL}, \mathrm{HbA} 1 \mathrm{C}$ and $\mathrm{CRP}$ were not elevated. $61.8 \%$ of the participants showed an abnormally large waist circumference and $23.6 \%$ had an increased BMI. By adapting the criteria of the IDF, systolic blood pressure changes were detected in $52.7 \%$ of the cases whereas diastolic blood pressure changes were found in $49.1 \%$ of the cases.

Cardiovascular risk factors were also taken into account for the diagnosis of metabolic syndrome according to the IDF (11). In the group of examined POs a distinct trend towards obesity became apparent. When considering lipid profile percentages, elevated triglyceride was most frequently detected (43.6\%). The major cardiovascular risk factors are shown in Table 3. 
Table 2

Classification of systolic and diastolic blood pressure in degrees of severity (7).

\begin{tabular}{|c|c|c|c|c|c|c|c|}
\hline & \multicolumn{7}{|c|}{ Systolic blood pressure } \\
\hline & $\mathbf{n}$ & $\begin{array}{l}\text { Optimum } \\
(\leq \leq \\
120 \mathrm{mmHg})\end{array}$ & $\begin{array}{l}\text { Normal } \\
(120- \\
129 \mathrm{mmHg})\end{array}$ & $\begin{array}{l}\text { High } \\
\text { normal } \\
(130- \\
139 \mathrm{mmHg})\end{array}$ & $\begin{array}{l}\text { Stage } 1 \\
\text { hypertension } \\
(140- \\
159 \mathrm{mmHg})\end{array}$ & $\begin{array}{l}\text { Stage } 2 \\
\text { hypertension } \\
(160- \\
179 \mathrm{mmHg})\end{array}$ & $\begin{array}{l}\text { Stage } 3 \\
\text { hypertension } \\
(> \\
180 \mathrm{mmHg})\end{array}$ \\
\hline \multirow{5}{*}{$\begin{array}{l}\text { Police } \\
\text { officers }\end{array}$} & 55 & $7(12.7 \%)$ & 19 & 16 & 12 & 1 & 0 \\
\hline & & & $(34.5 \%)$ & $(29.1 \%)$ & $(21.8 \%)$ & $(1.8 \%)$ & $(0 \%)$ \\
\hline & \multicolumn{7}{|c|}{ Diastolic blood pressure } \\
\hline & $\mathbf{n}$ & Optimum & Normal & $\begin{array}{l}\text { High } \\
\text { normal }\end{array}$ & $\begin{array}{l}\text { Stage } 1 \\
\text { hypertension }\end{array}$ & $\begin{array}{l}\text { Stage } 2 \\
\text { hypertension }\end{array}$ & $\begin{array}{l}\text { Stage } 3 \\
\text { hypertension }\end{array}$ \\
\hline & & $80 \mathrm{mmHg})$ & & $\begin{array}{l}(85- \\
89 \mathrm{mmHg})\end{array}$ & $\begin{array}{l}(90- \\
99 \mathrm{mmHg})\end{array}$ & $\begin{array}{l}(100- \\
109 \mathrm{mmHg})\end{array}$ & $\stackrel{(>}{110 \mathrm{mmHg})}$ \\
\hline \multirow{2}{*}{$\begin{array}{l}\text { Police } \\
\text { officers }\end{array}$} & 55 & $6(10.9 \%)$ & 22 & 0 & 18 & 7 & 2 \\
\hline & & & $(40.0 \%)$ & $(0 \%)$ & $(32.7 \%)$ & $(12.7 \%)$ & $(3.6 \%)$ \\
\hline
\end{tabular}


Table 3

Representation of major cardiovascular risk factors in the study population.

\begin{tabular}{|c|c|c|c|c|c|c|}
\hline & \multicolumn{6}{|c|}{ Police officers } \\
\hline & $\mathrm{n}$ & Mean & SD & Median & Normal (\%) & Abnormal (\%) \\
\hline Age (Years) & 55 & 45.3 & 7.8 & 45.0 & & \\
\hline \multicolumn{7}{|l|}{ Basic dimensions } \\
\hline Weight (kg) & 55 & 93.6 & 13.2 & 91.3 & & \\
\hline $\mathrm{BMI}\left(\mathrm{kg} / \mathrm{m}^{2}\right)$ & 55 & 28.0 & 3.2 & 27.4 & $42(76.4 \%)$ & $13(23.6 \%)$ \\
\hline Abdominal waist $(\mathrm{cm})$ & 55 & 97.8 & 12.4 & 96.0 & $21(38.2 \%)$ & $34(61.8 \%)$ \\
\hline \multicolumn{7}{|l|}{ Blood pressure } \\
\hline RRsrest (mmHg) & 55 & 127.7 & 12.3 & 130.0 & $26(47.3 \%)$ & $29(52.7 \%)$ \\
\hline RRdrest $(\mathrm{mmHg})$ & 55 & 85.7 & 10.2 & 83.0 & $28(50.9 \%)$ & $27(49.1 \%)$ \\
\hline \multicolumn{7}{|l|}{ Heart rate } \\
\hline Heart rate (beats/min.) & 55 & 68.9 & 11.4 & 67.0 & & \\
\hline \multicolumn{7}{|l|}{ Drink and tabacco } \\
\hline Tabacco use (Cigarettes/day) & 55 & 2.52 & 5.98 & 0.00 & & \\
\hline Alcohol (days a week) & 55 & 1.52 & 1.61 & 1.00 & & \\
\hline \multicolumn{7}{|l|}{ Blood values } \\
\hline Cholesterol (mg/dl) & 55 & 205.9 & 40.4 & 198.0 & & \\
\hline $\mathrm{HDL}(\mathrm{mg} / \mathrm{dl})$ & 55 & 49.4 & 15.3 & 45.0 & $39(70.9 \%)$ & $16(29.1 \%)$ \\
\hline $\mathrm{LDL}(\mathrm{mg} / \mathrm{dl})$ & 55 & 129.1 & 37.7 & 119.0 & & \\
\hline Triglyceride (mg/dl) & 55 & 185.1 & 145.4 & 133.0 & $31(56.4 \%)$ & $24(43.6 \%)$ \\
\hline HbA1c (\%) & 55 & 5.5 & 0.4 & 5.4 & & \\
\hline $\mathrm{CRP}(\mathrm{mg} / \mathrm{dl})$ & 55 & 0.21 & 0.21 & 0.10 & & \\
\hline
\end{tabular}

\subsubsection{Cardiovascular Risk Profile by Framingham}

In Table 4, the 10-year risk for cardiovascular events and the heart/vascular age (years) shown are based on the Framingham Risk score.

The examined POs showed a mean 10-year cardiovascular system risk of $9.6 \pm 7.4 \%$ and a mean heart/vascular age of 51.1. \pm 13.9 years. They exceeded their actual mean age of 45.3 years by 5.8 years. 
Table 4

Representation of the 10-year risk of cardiovascular events and heart/vascular age of the study population.

\begin{tabular}{|c|c|c|c|c|}
\hline & $\mathbf{n}$ & Mean & SD & Median \\
\hline \multicolumn{5}{|c|}{ Ten year-risk Framingham (\%) } \\
\hline Police officers & 55 & 9.6 & 7.4 & 7.6 \\
\hline \multicolumn{5}{|c|}{ Heart/Vascular Age by Framingham (Years) } \\
\hline Police officers & 55 & 51.1 & 13.9 & 50.0 \\
\hline
\end{tabular}

\subsubsection{Metabolic Syndrome}

In the group of POs a metabolic syndrome was detected in 18 of 55 participants according to the criteria of the International Diabetes Federation (IDF). This corresponded to 32.7\% (Table 5).

Table 5

Diagnosis metabolic syndrome (number / frequency ) according to the criteria of the IDF (16).

\begin{tabular}{|llll|}
\hline & $\mathbf{n}$ & No Metabolic Syndrome & Metabolic \\
& & & Syndrome \\
\hline Police officers & 55 & 37 & 18 \\
& & $(67.3 \%)$ & $(32.7 \%)$ \\
\hline
\end{tabular}

\subsubsection{Cardiorespiratory Fitness}

The relative oxygen uptake (rel. $\mathrm{VO}_{2 \mathrm{max}}$ ) was $34.1 \pm 8.0 \mathrm{ml} / \mathrm{kg}^{-1} \cdot \mathrm{min}^{-1}$ (Table 6). An absolute oxygen uptake (abs. $\mathrm{VO}_{2 \max }$ ) of $3.13 \pm 0.62 \mathrm{l} / \mathrm{min}$ was shown. The maximum achieved wattage was $288.5 \pm 48.6 \mathrm{~W}$, while watt per kilogram was $3.14 \pm 0.68 \mathrm{~W} / \mathrm{kg}$. Spiroergometry exercise parameters are displayed in Table 6 . 
Table 6

Spiroergometry and physical activity results of police officers.

\begin{tabular}{|c|c|c|c|c|}
\hline \multicolumn{5}{|c|}{ Police officers } \\
\hline & n & Mean & SD & Median \\
\hline & \multicolumn{4}{|c|}{ Ventilator aerobic threshold (AT) } \\
\hline $\mathrm{Hr}$ & 55 & 110.9 & 15.8 & 110.0 \\
\hline abs. V02 & 55 & 1.64 & 0.49 & 1.51 \\
\hline rel. V02 & 55 & 17.9 & 5.8 & 17.0 \\
\hline$\%$ V02max & 55 & 52.3 & 13.8 & 52.0 \\
\hline \multirow[t]{2}{*}{ W } & 55 & 133.6 & 41.7 & 132.0 \\
\hline & \multicolumn{4}{|c|}{ Respiratory compensation point (RCP) } \\
\hline $\mathrm{Hr}$ & 55 & 133.9 & 21.2 & 132.0 \\
\hline abs.VO2 & 55 & 2.24 & 0.73 & 2.16 \\
\hline rel.VO2 & 55 & 24.4 & 8.6 & 24.0 \\
\hline$\%$ V02max & 55 & 70.5 & 17.1 & 71.0 \\
\hline \multirow[t]{2}{*}{ w } & 55 & 193.2 & 61.9 & 188.0 \\
\hline & \multicolumn{4}{|c|}{ Maximum Loading (Max) } \\
\hline $\mathrm{Hr}$ & 55 & 172.4 & 16.2 & 172.0 \\
\hline abs. $\mathrm{VO}_{2}$ & 55 & 3.13 & 0.62 & 3.12 \\
\hline rel. $\mathrm{VO}_{2}$ & 55 & 34.1 & 8.0 & 34.0 \\
\hline W & 55 & 288.5 & 48.6 & 300.0 \\
\hline $\mathrm{W}_{\max / \mathrm{kg}}$ & 55 & 3.14 & 0.68 & 3.27 \\
\hline Dynamic METS & 55 & 2838 & 2872 & 1978 \\
\hline \multicolumn{5}{|l|}{ Abbreviations } \\
\hline Hr: Heart rate (min) & & \multicolumn{3}{|c|}{ abs. V02: Absolute maximal oxygen uptake ( $1 / \mathrm{min})$} \\
\hline $\begin{array}{l}\text { rel. V02: Relative maximal oxygen } \\
\text { uptake }(\mathrm{ml} / \mathrm{min} / \mathrm{kg})\end{array}$ & & \multicolumn{3}{|c|}{$\begin{array}{l}\text { \%VO2max: Percent of absolute maximal oxygen } \\
\text { uptake }(1 / \mathrm{min})\end{array}$} \\
\hline W: Watt & & \multicolumn{3}{|c|}{ Wmax/kg: Watt maximal per kg body weight } \\
\hline
\end{tabular}

\section{Discussion}




\subsection{Cardiovascular Risk}

In general, working condition at the police force are reported as a risk factor for the development of cardiovascular diseases, diabetes mellitus and higher rates of mortality $(1,2,4)$. Not only German police officers are found to be at a higher risk for cardiovascular disease, when in fact this seems to be a global problem affecting law enforcement. It is likely that various factors in terms of the working conditions are the cause for this. Police patrols are scheduled according to shift work. Furthermore, the majority of work time involves sitting in patrol cars, writing reports, or interviewing persons, placing the officer at a higher risk for obesity.

It is known that occupational sitting time is independently associated with the presence of overweight and obesity and other cardiovascular risk factors in men $(17,18)$. The time of sedentary work activity was found to be related to an increased waist circumference, elevated serum triglyceride and serum CRP levels and lower HDL cholesterol levels and it can accelerate the emergence and progression of cardiovascular disease $(18,19)$.

Thomas et al. could provide evidence of a link between shift work and a higher level of cardiovascular risk. (20). Workers on night duty generally show a significantly higher BMI as well as higher levels of cholesterol and triglyceride than workers on day shift (21). It is fair to assume that these factors also play an important role in the development of cardiovascular risk to the police officers in our study.

In our group of POs the mean blood lipid levels, depicting cardiovascular risk, were increased above the upper limit of the healthy reference range with the exception of total cholesterol $(205.9 \pm 40.4)$ and triglyceride (185.1 \pm $145.4)$ values. Compared to Swiss police officers, the analyzed German cohort showed higher median results for $\mathrm{BMI}$, waist circumference, cholesterol, LDL and levels of triglyceride (22). The German cohort show also higher median results when compared to the results of international studies. A comparison of cardiovascular risk factors in published studies is shown in Table 7.

Regarding blood pressure values in the examined POs, a systolic hypertension was observed in $52.7 \%$, and diastolic hypertension was observed in $49.1 \%$, based on criteria for metabolic syndrome of the IDF.

The presence of hypertension is not only notable in our study cohort but can be observed in the entire population and other occupational groups $(23,24)$. It seemed the prevalence of arterial hypertension in the group of German POs was higher compared to the general German population. Estimates show that slightly over $30 \%$ of the German population show arterial hypertensive blood pressure values (25). In international comparison, our study cohort shows values of systolic and diastolic blood pressure at the same levels as police officers from the USA, India and Switzerland $(22,26,27)$. Lower values are described in a Saudi Arabia police officer cohort (28).

One of the most important cardiovascular risk factors is smoking. The prevalence of our examined cohort of nicotine consumption was $18.2 \%$. An international comparison shows that the smoking status of police officers differs greatly. However, studies show that there is a link between shift work, specifically working the night shift, and higher consumption of nicotine (21).

In this study we routinely analyzed lipoprotein (a) in our cohort. Lipoprotein (a) represents an important cardiovascular risk parameter. Elevated values of this parameter are associated with an increased cardiovascular risk profile and may - in conjunction with other cardiovascular risk factors - increase the risk for vascular diseases $(29,30)$. Lipoprotein $(a)$ is a genetically determined parameter and appears to play a central role in the development of coronary artery diseases and thromboembolic events $(31,32)$. Kamstrup et al. (30) 
demonstrated in males with increased lipoprotein (a) levels in combination with other important cardiovascular risk parameters a $35 \%$ higher 10-year risk suffering myocardial infarction. $25.5 \%$ of German police officers show an increased value of Lipoprotein (a). An international comparison to police officers of other studies is not possible because of the lack of data.

In order to establish the 10-year risk for cardiovascular events, the "Farmingham risk score" was used. The 10year risk for cardiovascular events of our analyzed cohort was found to be at $9.6 \pm 7.4 \%$.

When dividing the Framingham risk score in categories of low, moderate, high and very high risk, our study population could be classified in the 'low risk' category, according to a 10-year chance on cardiovascular events being $<10 \%$ (33). A direct and valid comparison of the 10-year risk stratification of cardiovascular events in POs in international studies could not be carried out due to the lack of comparative studies by using the same risk score. To date, there is only one study of American police officers which found there to be a lower chance of cardiovascular events in 10 years' time (MW \pm SD: $1.2 \pm 0.5)(27)$. 
Table 7

Comparison of cardiovascular risk factors in published studies of police officers

\begin{tabular}{|c|c|c|c|c|c|c|c|}
\hline \multicolumn{8}{|c|}{ Cardiovascular risk factors } \\
\hline Source & $\begin{array}{l}\text { Own } \\
\text { results }\end{array}$ & $\begin{array}{l}\text { Schilling et } \\
\text { al. (22) }\end{array}$ & $\begin{array}{l}\text { Thayyil } \\
\text { et al. } \\
\text { (34) }\end{array}$ & $\begin{array}{l}\text { Tharkar } \\
\text { et al. } \\
\text { (26) }\end{array}$ & $\begin{array}{l}\text { Violanti } \\
\text { et al. } \\
\text { (35) }\end{array}$ & $\begin{array}{l}\text { Everding } \\
\text { et al. } \\
\text { (27) }\end{array}$ & $\begin{array}{l}\text { Alghamdi et } \\
\text { al. (28) }\end{array}$ \\
\hline \multirow[t]{2}{*}{ Study cohort } & \multirow[t]{2}{*}{$\begin{array}{l}\text { Police } \\
\text { officers } \\
\text { Germany }\end{array}$} & $\begin{array}{l}\text { Police } \\
\text { officers }\end{array}$ & $\begin{array}{l}\text { Police } \\
\text { officers }\end{array}$ & \multirow[t]{2}{*}{$\begin{array}{l}\text { Police } \\
\text { officers } \\
\text { India }\end{array}$} & \multirow[t]{2}{*}{$\begin{array}{l}\text { Police } \\
\text { officers } \\
\text { USA }\end{array}$} & \multirow[t]{2}{*}{$\begin{array}{l}\text { Police } \\
\text { officers } \\
\text { USA }\end{array}$} & \multirow[t]{2}{*}{$\begin{array}{l}\text { Police } \\
\text { officers } \\
\text { Saudi Arabia }\end{array}$} \\
\hline & & Switzerland & India & & & & \\
\hline Study cohort & 55 & 201 & 823 & 318 & 58 & 379 & 160 \\
\hline Age (Years) & $45.3 \pm 7.8$ & $38.6 \pm 10.1$ & $\begin{array}{l}41.3 \pm \\
6.8\end{array}$ & $\begin{array}{l}44.3 \pm \\
12.1\end{array}$ & $\begin{array}{l}44.0 \pm \\
8.7\end{array}$ & $\begin{array}{l}41.5 \pm \\
8.6\end{array}$ & $34.4 \pm 8.3$ \\
\hline Weight (kg) & $93.6 \pm 13.2$ & & $\begin{array}{l}71.3 \pm \\
8.4\end{array}$ & & $\begin{array}{l}94.5 \pm \\
14.2\end{array}$ & & $79.0 \pm 15.2$ \\
\hline $\mathrm{BMI}\left(\mathrm{kg} / \mathrm{m}^{2}\right)$ & $28.0 \pm 3.2$ & $25.8 \pm 3.6$ & $\begin{array}{l}23.9 \pm \\
2.5\end{array}$ & $\begin{array}{l}25.9 \pm \\
4.1\end{array}$ & $\begin{array}{l}29.8 \pm \\
5.8\end{array}$ & $\begin{array}{l}28.8 \pm \\
3.9\end{array}$ & $27.5 \pm 5.1$ \\
\hline $\begin{array}{l}\text { Abdominal } \\
\text { waist (cm) }\end{array}$ & $97.8 \pm 12.4$ & $91.1 \pm 11.3$ & $\begin{array}{l}85.9 \pm \\
11.9\end{array}$ & $\begin{array}{l}92.5 \pm \\
11.6\end{array}$ & & & \\
\hline $\begin{array}{l}\text { Number of } \\
\text { smokers (\%) }\end{array}$ & 18.2 & & 10.6 & 22.6 & & & \\
\hline $\mathrm{RRs}_{\text {Rest }(\mathrm{mmHg})}$ & $\begin{array}{l}127.7 \pm \\
12.3\end{array}$ & $\begin{array}{l}129.0 \pm \\
13.0\end{array}$ & $\begin{array}{l}125.2 \\
\pm 13.4\end{array}$ & $\begin{array}{l}128.3 \pm \\
18.8\end{array}$ & $\begin{array}{l}122.6 \pm \\
14.9\end{array}$ & $\begin{array}{l}125.1 \pm \\
8.6\end{array}$ & $119.5 \pm 13.9$ \\
\hline $\mathrm{RR}_{\mathrm{dRest}(\mathrm{mmHg})}$ & $85.7 \pm 10.2$ & $85.0 \pm 10.0$ & $\begin{array}{l}82.0 \pm \\
9.0\end{array}$ & $\begin{array}{l}85.5 \pm \\
12.5\end{array}$ & $\begin{array}{l}81.2 \pm \\
10.4\end{array}$ & $\begin{array}{l}85.1 \pm \\
7.6\end{array}$ & $79.4 \pm 11.9$ \\
\hline $\begin{array}{l}\text { Cholesterol } \\
(\mathrm{mg} / \mathrm{dl})\end{array}$ & $\begin{array}{l}205.9 \pm \\
40.4\end{array}$ & $\begin{array}{l}192.3 \pm \\
38.5\end{array}$ & $\begin{array}{l}207.2 \\
\pm 40.2\end{array}$ & $\begin{array}{l}183.6 \pm \\
42.8\end{array}$ & & $\begin{array}{l}190.2 \pm \\
32.9\end{array}$ & $187.5 \pm 32.9$ \\
\hline $\mathrm{HDL}(\mathrm{mg} / \mathrm{dl})$ & $49.4 \pm 15.3$ & $69.2 \pm 15.4$ & $\begin{array}{l}49.1 \pm \\
11.3\end{array}$ & $\begin{array}{l}39.8 \pm \\
10.5\end{array}$ & & $\begin{array}{l}49.4 \pm \\
13.3\end{array}$ & $43.9 \pm 8.6$ \\
\hline LDL (mg/dl) & $\begin{array}{l}129.1 \pm \\
37.7\end{array}$ & $96.2 \pm 30.8$ & $\begin{array}{l}129.0 \\
\pm 38.8\end{array}$ & $\begin{array}{l}106.9 \pm \\
38.4\end{array}$ & & $\begin{array}{l}115.1 \pm \\
28.0\end{array}$ & $119.5 \pm 24.4$ \\
\hline $\begin{array}{l}\text { Triglyceride } \\
(\mathrm{mg} / \mathrm{dl})\end{array}$ & $\begin{array}{l}185.1 \pm \\
145.4\end{array}$ & $\begin{array}{l}150.4 \pm \\
106.2\end{array}$ & $\begin{array}{l}143.0 \\
\pm 56.9\end{array}$ & $\begin{array}{l}177.6 \pm \\
116\end{array}$ & & $\begin{array}{l}145.8 \pm \\
84.7\end{array}$ & $124.5 \pm 50.9$ \\
\hline $\mathrm{HbA1c}(\%)$ & $5.5 \pm 0.4$ & $5.4 \pm 0.3$ & & & & & \\
\hline $\begin{array}{l}\text { Ten year-risk } \\
\text { Framingham } \\
(\%)\end{array}$ & $9.6 \pm 7.4$ & & & & & $1.2 \pm 0.5$ & \\
\hline $\begin{array}{l}\text { Lipoprotein a } \\
>30 \mathrm{mg} / \mathrm{dl}(\%)\end{array}$ & 25.5 & & & & & & \\
\hline
\end{tabular}

\subsection{Metabolic Syndrome}


International studies confirm an increased risk for metabolic syndrome in POs $(26,36,37)$. In our study the definition of the International Diabetes Federation (IDF) was used for diagnosis of metabolic syndrome (16). The definition of IDF is well-validated, posing adipositas as the central factor for defining the metabolic syndrome. In comparison with other studies the definition of IDF is more likely to be used in central Europe than definitions of National Cholesterol Education Program (NCEP) and World Health Organization (WHO) $(38,39)$. POs in our study cohort showed a mean waist circumference of $97.8 \pm 12.4 \mathrm{~cm}$. BMI was within the overweight range with a mean of $28.0 \pm 3.2 \mathrm{~kg} / \mathrm{m} 2$. Examined POs from Switzerland and India displayed lower mean abdominal circumferences and BMI values compared to our German cohort $(22,34)$. Mean values of American POs concerning BMI are at the same range to our German POs, but American POs had lower mean values concerning the lipid profile (Cholesterol, LDL and Triglyercide) $(27,35)$. However, an increased abdominal circumferences and BMI do not appear to be exclusive to our investigated German cohort; they are globally detectable in police forces.

One reason of high abdominal circumferences in POs examined in our study seemed to be caused by sedentary work activities. But the impact of this fact is unkown. It is known that prolonged sedentary activities are associated with higher abdominal circumferences and the severity of the associated metabolic risk (40).

According to criteria of the IDF the metabolic syndrome was detected in $32.7 \%$ of probands in our study. Looking at various studies around the world the prevalence of metabolic syndrome in the general population varies from $23 \%$ France to $41 \%$ in USA (41). Compared to the regional prevalence of metabolic syndrome of the male population of North Rhine-Westphalia (Germany), the analyzed POs were found to be at an above-average risk of metabolic syndrome (males in North Rhine-Westphalia: $22 \%$ vs. POs: $32 \%$ ) (42). These results correspond to the conclusion drawn by Tharkar et al. (26). It was shown that Indian POs had a significantly higher risk for MetS than the rest of the population ( $57.3 \%$ vs $28.2 \%$ ). However, Hartley et al. (43) detected a lower prevalence of the metabolic syndrome at $26.7 \%$ of the analyzed cohort in the BCOPS study. The lowest prevalence of metabolic syndrome was found by Violanti et al. (44) among POs in USA (13.3\%) and one of the highest were described for POs in Poland (53.6\%) (36). Table 8 shows a comparison of the prevalence of metabolic syndrome in the professional category of "Police officers" among countries. 
Table 8

Prevalence of Metabolic Syndrome in published studies.

\begin{tabular}{|llll|}
\hline Prevalence of Metabolic Syndrome & & \\
\hline Police officers & & & \\
\hline Source & Prevalence (\%) & Country & Criteria \\
\hline Own results & 32.7 & Germany & IDF \\
\hline Tharkar et al.(26) & 57.3 & India & IDF \\
\hline Thayyil et al.(34) & 16.8 & India & Modified NCEP / ATP III \\
\hline Garbarino et al. (46) & 24.5 & Italy & IDF and NCEP / ATP III \\
\hline Hartley et al.(43) & 26.7 & USA & Modified NCEP / ATP III \\
\hline McCanlies et al.(49) & 22.0 & USA & NCEP / ATP III \\
\hline Everding et al. (27) & 29.0 & USA & IDF \\
\hline Violanti et al. (44) & 13.3 & USA & Modified NCEP / ATP III \\
\hline Janczura et al. (36) & 53.6 & Poland & IDF \\
\hline Zhang et al. (37) & 26.0 & China & IDF \\
\hline
\end{tabular}

It can be assumed there are multifactorial reasons for high prevelance of metabolic syndrome in POs exist. In a study by Janczura et al. (45), it was shown that there is a correlation between "perceived stress" (Perceived Stress Scale-10) on the job and a higher prevalence of the metabolic syndrome in Polish police officers. Garbarino et al. (46) supports this result, proving that work-related stress induces the metabolic syndrome. The prevalence was found to be at $24.5 \%$ in the analyzed male police officers. Furthermore, the irregular work hours, specifically those at night, can trigger sleeping disorders $(47,48)$. It is safe to assume that a high number of German police officers also suffer from a sleeping disorder. A connection to the higher prevalence of metabolic syndrome is therefore quite possible. The study by McCanlies has shown that POs who claimed to sleep less than 6 hours per 24 hours had an increased prevalence for the metabolic syndrome by $150 \%$ in comparison to those POs who stated to sleep more than 6 hours per 24 hours (49).

It may seem surprising that German POs show a similarly high risk of metabolic syndrome to office workers (24, 50). This could be due to the fact that both occupations conduct activities mostly while sitting. It is well known that sedentary activities carry a higher risk for metabolic syndrome (51) and cardiovascular disease (52).

Overall differences in individual status and private and professional activities exist and there will also be differences concerning the way of life between the countries. Therefore, in the future there is a need to perform prospective studies concern these factors.

\subsection{Cardiorespiratory Fitness}

High cardiorespiratory fitness is an important factor in the prevention and treatment of cardiovascular risk, diseases and mortality $(53,54)$. In detail, higher cardiorespiratory fitness is associated with lower BMI, a lower 
risk for development type 2 diabetes and being active $(55,56)$. Physical fitness is an important basic requirement for police officers on duty. As we know, there are only few researches about cardiorespiratory fitness among police officers. A direct comparison of the data investigated is challenging because of diverging parameters in age and BMI between the study groups. In our study the examined POs reached a mean oxygen uptake of (rel. $\mathrm{VO}_{2 \max }$ ) $34.1 \pm 8.0 \mathrm{ml} / \mathrm{kg}^{-1} \mathrm{~min}^{-1}$. When compared to police officers of other countries, the rel. $\mathrm{VO}_{2 \mathrm{max}}$ values of German POs are the lowest. But the comparison suffers from a lack of available study data. Comparison to international literature German police officers shows the lowest relative oxygen uptakes. Canadian police officers have the highest relative oxygen uptake $\left(32.4 \pm 5.4 \mathrm{ml} / \mathrm{kg}^{-1} \mathrm{~min}^{-1}\right)(57)$ and police officers from America and Finland also showed higher values $(58,59)$. A comparative presentation of relative oxygen uptake is shown in Table 9. In general, the $\mathrm{VO}_{2 \mathrm{max}}$ values estimated in German police officers seemed to be lower to the range of values in healthy participants (rel. V02max: $40.5 \pm 5.5 \mathrm{vs} .34 .1 \pm 8.0 \mathrm{ml} / \mathrm{kg}-1 \cdot \mathrm{min}-1$.) (60). Compared to recreational athletes $\mathrm{VO}_{2 \max }$ assessed in our study is expectedly lower (rel. V02max: 64.7 \pm 6.7 vs. $34.1 \pm 8.0 \mathrm{ml} / \mathrm{kg}-1 \cdot \mathrm{min}-1$.) (61), but almost identical compared to a mainly sedentary working group of German office workers (rel. V02max: $34.1 \pm 8.1$ vs. $34.1 \pm 8.0 \mathrm{ml} / \mathrm{kg}-1 \cdot \mathrm{min}-1$.) (24). A group of professional firefighters with high degrees of physical activity at work also showed higher values of oxygen uptake (rel. V02max: $37.3 \pm 6.3$ vs. $34.1 \pm 8.0 \mathrm{ml} / \mathrm{kg}-1 \cdot \mathrm{min}-1$.) $(23)$.

Table 9

Published data of relative oxygen uptake $\left(\right.$ rel. $\mathrm{VO}_{2 \text { max }}$ ) by police officers and healthy participants.

\begin{tabular}{|llll|}
\hline Police officers & \multicolumn{3}{c|}{ Healthy participants } \\
\hline Source & rel. $\mathrm{VO}_{2 \mathrm{max}}$ & Source & rel. $\mathrm{VO}_{2 \mathrm{max}}$ \\
& $\left(\mathrm{ml} / \mathrm{kg}^{-1} \cdot \mathrm{min}^{-1}\right)$ & & $\left(\mathrm{ml} / \mathrm{kg}^{-1} \cdot \mathrm{min}^{-1}\right)$ \\
\hline Own results & $34.1 \pm 8.0$ & & \\
\hline Pollock et al. (58) & $40.7 \pm 4.5$ & Duque et al. (60) & $40.5 \pm 5.5$ \\
\hline Spitler et al.(62) & $42.1 \pm 8.9$ & & \\
\hline Sörensen et al.(59) & $42.8 \pm 10.1$ & & \\
\hline Rhodes et al.(57) & $44.1 \pm 6.6$ & & \\
\hline Lentz et al. (63) & $42.2 \pm 5.8$ & & \\
\hline
\end{tabular}

\section{Conclusions}

To our knowledge this study was one of the first to assess data on cardiovascular health, metabolic syndrome and cardiorespiratory status of police officers in Germany. The results of our study population demonstrated an increased cardiovascular risk of German police officers and displaying a low cardiorespiratory fitness. A high prevalence of elevated cardiovascular and metabolic risk factors is detected in our cohort, especially a high prevalence of increased diastolic and systolic blood pressure at rest and increased cholesterol and triglyceride values. A trend towards obesity could be seen in investigated individuals and general in the police force. An 
increased abdominal circumferences and BMI do not appear to be exclusive to our German POs cohort; they are globally detectable in the context of "police officers". However, the cardiovascular risk profile of our examined German cohort seems to be in the higher range in comparison to international data and the high prevalence of metabolic syndrome amongst POs was not exclusive to our German cohort but was identified globally.

A high cardiovascular fitness is a definite job requirement for law enforcement. The analyzed German POs have shown the worst cardiorespiratory fitness of rel. VO2max when compared internationally. This shows both the urgency and necessity for establishing fitness-related activities for the improvement of cardiovascular fitness.

In conclusion, the present study results demonstrated the need for implementation of interventions and creating health promoting concepts like corporate sports activities and nutrition courses to counteract cardiovascular and metabolic risk factors to subsequent the development of cardiovascular and metabolic disease in this occupational group.

\section{List Of Abbreviations}

AT

BMI

CRP

$\mathrm{HbA} 1 \mathrm{c} \%$

HDL

IDF

LDL

MET

PO

RCP

RR

rel. VO2max

abs.V02max
Ventilator aerobic threshold

Body Mass Index

C- reactive protein

glycated hemoglobin

High density lipoprotein

International Diabetes Federation

Low density lipoprotein

Metabolic equivalent

Police officer

Respiratory compensation point

Blood pressure

Relative maximal oxygen uptake

Absolute maximal oxygen uptake

\section{Declarations}

\section{Authors' contributions}

Study conception and design: MS, PF, RL. Data acquisition: MS, PF, RL. Data analysis and interpretation: MS, UJ, RL. Statistical analysis: MS, RV, RL. Drafting the manuscript: MS, RL. Critical revision of the manuscript for 
important intellectual content: MS, PF, UJ, RV, HL, RL. Final approval of the version to be published: MS, PF, UJ, RV, HL, RL. Obtained funding: RL. Administrative, technical, or material support: MS, PF, RL. All authors read and approved the final manuscript.

\section{Acknowledgements}

We thank Hiltrud Niggemann for the support by statistical analysis.

\section{Author details}

1. Department of Cardiology I- Coronary and Peripheral Vascular Disease, Heart Failure Medicine, University Hospital Muenster, Cardiol, 48149 Muenster, Germany

2. Department of Cardiology, Sector Preventive Medicine, Health Promotion, Faculty of Health, School of Medicine, University Witten/Herdecke, 58095 Hagen, Germany

3. Department of Medicine D, Division of General Internal Medicine, Nephrology and Rheumatology, University Hospital of Muenster, 48149 Muenster, Germany

4. Department of Medicine B, Gastroenterology and Hepatology, University Hospital Münster, 48149 Muenster, Germany

\section{Availability of data and materials}

The datasets analysed during the current study are available from the corresponding author on reasonable request.

\section{Ethics approval and consent to participate}

The study was approved by the human research ethics committee at University of Witten/Herdecke. All subjects provided written informed consent.

\section{Consent for publication}

All the authors listed have approved the manuscript for publication.

\section{Competing interests}

The authors declare that they have no competing interests.

\section{Funding acknowledgment statement}

This research received no specific grant from any funding agency in the public, commercial, or not-for-profit sectors.

\section{References}


1. Mona GG, Chimbari MJ, Hongoro C. A systematic review on occupational hazards, injuries and diseases among police officers worldwide: Policy implications for the South African Police Service. Journal of occupational medicine and toxicology (London, England). 2019;14:2-.

2. Zimmerman FH. Cardiovascular disease and risk factors in law enforcement personnel: a comprehensive review. Cardiology in review. 2012;20(4):159-66.

3. Plat MJ, Frings-Dresen MH, Sluiter JK. A systematic review of job-specific workers' health surveillance activities for fire-fighting, ambulance, police and military personnel. International archives of occupational and environmental health. 2011;84(8):839-57.

4. Varvarigou V, Farioli A, Korre M, Sato S, Dahabreh IJ, Kales SN. Law enforcement duties and sudden cardiac death among police officers in United States: case distribution study. BMJ (Clinical research ed). 2014;349:g6534.

5. American S. Why Is Swimming the Most Deadly Leg of a Triathlon 2011 [Available from: http://www.scientificamerican.com/article/triathlon-death-swimming/.

6. Ainsworth BE, Haskell WL, Herrmann SD, Meckes N, Bassett DR, Jr., Tudor-Locke C, et al. 2011 Compendium of Physical Activities: a second update of codes and MET values. Medicine and science in sports and exercise. 2011;43(8):1575-81.

7. Williams B, Mancia G, Spiering W, Agabiti Rosei E, Azizi M, Burnier M, et al. 2018 ESC/ESH Guidelines for the management of arterial hypertension. European heart journal. 2018;39(33):3021-104.

8. Ackland TR, Lohman TG, Sundgot-Borgen J, Maughan RJ, Meyer NL, Stewart AD, et al. Current status of body composition assessment in sport: review and position statement on behalf of the ad hoc research working group on body composition health and performance, under the auspices of the I.O.C. Medical Commission. Sports medicine. 2012;42.

9. Anderson KM, Odell PM, Wilson PW, Kannel WB. Cardiovascular disease risk profiles. American heart journal. 1991;121(1 Pt 2):293-8.

10. Study FH. Ten Years Cardiovascular Disease Risk https://www.framinghamheartstudy.org/riskfunctions/cardiovascular-disease/10-year-risk.php [

11. Alberti KG, Zimmet P, Shaw J. Metabolic syndrome--a new world-wide definition. A Consensus Statement from the International Diabetes Federation. Diabetic medicine : a journal of the British Diabetic Association. 2006;23(5):469-80.

12. Wasserman K, Whipp BJ, Koyl SN, Beaver WL. Anaerobic threshold and respiratory gas exchange during exercise. Journal of applied physiology. 1973;35(2):236-43.

13. Steding K, Buhre T, Arheden H, Wohlfart B. Respiratory indices by gas analysis and fat metabolism by indirect calorimetry in normal subjects and triathletes. Clinical physiology and functional imaging. 2010;30(2):146-51.

14. Beaver WL, Wasserman K, Whipp BJ. A new method for detecting anaerobic threshold by gas exchange. Journal of applied physiology (Bethesda, Md : 1985). 1986;60(6):2020-7.

15. Grundy SM, Pasternak R, Greenland P, Smith S, Jr., Fuster V. Assessment of cardiovascular risk by use of multiple-risk-factor assessment equations: a statement for healthcare professionals from the American Heart Association and the American College of Cardiology. Circulation. 1999;100(13):1481-92. 
16. Alberti KG, Zimmet P, Shaw J. The metabolic syndrome--a new worldwide definition. Lancet. 2005;366(9491):1059-62.

17. Mummery WK, Schofield GM, Steele R, Eakin EG, Brown WJ. Occupational sitting time and overweight and obesity in Australian workers. American journal of preventive medicine. 2005;29(2):91-7.

18. Healy GN, Matthews CE, Dunstan DW, Winkler EA, Owen N. Sedentary time and cardio-metabolic biomarkers in US adults: NHANES 2003-06. European heart journal. 2011;32(5):590-7.

19. Same RV, Feldman DI, Shah N, Martin SS, Al Rifai M, Blaha MJ, et al. Relationship Between Sedentary Behavior and Cardiovascular Risk. Current cardiology reports. 2016;18(1):6.

20. Thomas C, Power C. Shift work and risk factors for cardiovascular disease: a study at age 45 years in the 1958 British birth cohort. European journal of epidemiology. 2010;25(5):305-14.

21. Biggi N, Consonni D, Galluzzo V, Sogliani M, Costa G. Metabolic syndrome in permanent night workers. Chronobiology international. 2008;25(2):443-54.

22. Schilling R, Colledge F, Ludyga S, Pühse U, Brand S, Gerber M. Does Cardiorespiratory Fitness Moderate the Association between Occupational Stress, Cardiovascular Risk, and Mental Health in Police Officers? International journal of environmental research and public health. 2019;16(13):2349.

23. Strauß M, Karutz H, Foshag P, Spelsberg N, Dworrak B, Horlitz M, et al. Fit for rescue? Notfall + Rettungsmedizin. 2016:1-9.

24. Strauss M, Foshag P, Leischik R. Prospective Evaluation of Cardiovascular, Cardiorespiratory, and Metabolic Risk of German Office Workers in Comparison to International Data. International journal of environmental research and public health. 2020;17(5):1590.

25. Adler C, Schaffrath Rosario A, Diederichs C, Neuhauser HK. Change in the association of body mass index and systolic blood pressure in Germany - national cross-sectional surveys 1998 and 2008-2011. BMC public health. 2015;15:705.

26. Tharkar S, Kumpatla S, Muthukumaran P, Viswanathan V. High prevalence of metabolic syndrome and cardiovascular risk among police personnel compared to general population in India. The Journal of the Association of Physicians of India. 2008;56:845-9.

27. Everding B, Hallam JE, Kohut ML, Lee DC, Anderson AA, Franke WD. Association of Sleep Quality With Cardiovascular Disease Risk and Mental Health in Law Enforcement Officers. Journal of occupational and environmental medicine / American College of Occupational and Environmental Medicine. 2016;58(8):e2816.

28. Alghamdi AS, Yahya MA, Alshammari GM, Osman MA. Prevalence of overweight and obesity among police officers in Riyadh City and risk factors for cardiovascular disease. Lipids Health Dis. 2017;16(1):79-.

29. Ariyo AA, Thach C, Tracy R. Lp(a) lipoprotein, vascular disease, and mortality in the elderly. The New England journal of medicine. 2003;349(22):2108-15.

30. Kamstrup PR, Benn M, Tybjaerg-Hansen A, Nordestgaard BG. Extreme lipoprotein(a) levels and risk of myocardial infarction in the general population: the Copenhagen City Heart Study. Circulation. 2008;117(2):176-84.

31. Leischik R, Dworrak B. [Lipoprotein (a): importance for the fibrinolytic system and thromboembolic complications]. Herz. 2006;31(2):144-52. 
32. Leischik R, Dworrak B, Gulker H. [Lipoprotein(a) in coronary heart disease: clinical significance and therapeutic options]. Deutsche medizinische Wochenschrift (1946). 2005;130(44):2518-23.

33. Wilson PW, D'Agostino RB, Levy D, Belanger AM, Silbershatz H, Kannel WB. Prediction of coronary heart disease using risk factor categories. Circulation. 1998;97(18):1837-47.

34. Thayyil J, Jayakrishnan TT, Raja M, Cherumanalil JM. Metabolic syndrome and other cardiovascular risk factors among police officers. North American journal of medical sciences. 2012;4(12):630-5.

35. Violanti JM, Burchfiel CM, Miller DB, Andrew ME, Dorn J, Wactawski-Wende J, et al. The Buffalo CardioMetabolic Occupational Police Stress (BCOPS) pilot study: methods and participant characteristics. Ann Epidemiol. 2006;16(2):148-56.

36. Janczura M, Bochenek G, Nowobilski R, Dropinski J, Kotula-Horowitz K, Laskowicz B, et al. The Relationship of Metabolic Syndrome with Stress, Coronary Heart Disease and Pulmonary Function-An Occupational Cohort-Based Study. PloS one. 2015;10(8):e0133750-e.

37. Zhang J, Liu Q, Long S, Guo C, Tan H. Prevalence of metabolic syndrome and its risk factors among 10,348 police officers in a large city of China: A cross-sectional study. Medicine (Baltimore). 2019;98(40):e17306.

38. Executive Summary of The Third Report of The National Cholesterol Education Program (NCEP) Expert Panel on Detection, Evaluation, And Treatment of High Blood Cholesterol In Adults (Adult Treatment Panel III). Jama. 2001;285(19):2486-97.

39. Alberti KG, Zimmet PZ. Definition, diagnosis and classification of diabetes mellitus and its complications. Part 1: diagnosis and classification of diabetes mellitus provisional report of a WHO consultation. Diab Med. 1998;15.

40. Healy GN, Wijndaele K, Dunstan DW, Shaw JE, Salmon J, Zimmet PZ, et al. Objectively measured sedentary time, physical activity, and metabolic risk: the Australian Diabetes, Obesity and Lifestyle Study (AusDiab). Diabetes care. 2008;31(2):369-71.

41. Cameron AJ, Shaw JE, Zimmet PZ. The metabolic syndrome: prevalence in worldwide populations. Endocrinol Metab Clin North Am. 2004;33(2):351-75, table of contents.

42. Moebus S, Hanisch J, Bramlage P, Losch C, Hauner H, Wasem J, et al. Regional differences in the prevalence of the metabolic syndrome in primary care practices in Germany. Deutsches Arzteblatt international. 2008;105(12):207-13.

43. Hartley TA, Burchfiel CM, Fekedulegn D, Andrew ME, Knox SS, Violanti JM. Associations between police officer stress and the metabolic syndrome. International journal of emergency mental health. 2011;13(4):243-56.

44. Violanti JM, Fekedulegn D, Hartley TA, Andrew ME, Charles LE, Mnatsakanova A, et al. Police trauma and cardiovascular disease: association between PTSD symptoms and metabolic syndrome. International journal of emergency mental health. 2006;8(4):227-37.

45. Janczura M, Bochenek G, Nowobilski R, Dropinski J, Kotula-Horowitz K, Laskowicz B, et al. The Relationship of Metabolic Syndrome with Stress, Coronary Heart Disease and Pulmonary Function-An Occupational Cohort-Based Study. PloS one. 2015;10(8):e0133750.

46. Garbarino S, Magnavita N. Work Stress and Metabolic Syndrome in Police Officers. A Prospective Study. PloS one. 2015;10(12):e0144318. 
47. Fekedulegn D, Burchfiel CM, Charles LE, Hartley TA, Andrew ME, Violanti JM. Shift Work and Sleep Quality Among Urban Police Officers: The BCOPS Study. Journal of occupational and environmental medicine / American College of Occupational and Environmental Medicine. 2016;58(3):e66-71.

48. Lim YC, Hoe VCW, Darus A, Bhoo-Pathy N. Association between night-shift work, sleep quality and metabolic syndrome. Occupational and environmental medicine. 2018;75(10):716-23.

49. McCanlies EC, Slaven JE, Smith LM, Andrew ME, Charles LE, Burchfiel CM, et al. Metabolic syndrome and sleep duration in police officers. Work (Reading, Mass). 2012;43(2):133-9.

50. Strauß M, Foshag P, Przybylek B, Horlitz M, Lucia A, Sanchis-Gomar F, et al. Occupation and metabolic syndrome: is there correlation? A cross sectional study in different work activity occupations of German firefighters and office workers. Diabetology \& Metabolic Syndrome. 2016;8(1):1-8.

51. Edwardson CL, Gorely T, Davies MJ, Gray LJ, Khunti K, Wilmot EG, et al. Association of sedentary behaviour with metabolic syndrome: a meta-analysis. PloS one. 2012;7(4):e34916.

52. Ford ES, Caspersen CJ. Sedentary behaviour and cardiovascular disease: a review of prospective studies. International journal of epidemiology. 2012;41(5):1338-53.

53. Lavie CJ, Arena R, Swift DL, Johannsen NM, Sui X, Lee D-c, et al. Exercise and the cardiovascular system: clinical science and cardiovascular outcomes. Circulation research. 2015;117(2):207-19.

54. Myers J, Prakash M, Froelicher V, Do D, Partington S, Atwood JE. Exercise capacity and mortality among men referred for exercise testing. The New England journal of medicine. 2002;346(11):793-801.

55. Jackson AS, Sui X, Hebert JR, Church TS, Blair SN. Role of lifestyle and aging on the longitudinal change in cardiorespiratory fitness. Archives of internal medicine. 2009;169(19):1781-7.

56. Kawakami R, Sawada SS, Lee I-M, Gando Y, Momma H, Terada S, et al. Long-term impact of cardiorespiratory fitness on type 2 diabetes incidence: a cohort study of Japanese men. Journal of epidemiology. 2017:JE20170017.

57. Rhodes E, Farenholtz D. Police Officer's Physical Abilities Test compared to measures of physical fitness. Canadian journal of sport sciences= Journal canadien des sciences du sport. 1992;17(3):228-33.

58. Pollock ML, Gettman LR, Meyer BU. Analysis of Physical Fitness and Coronary Heart Disease Risk of Dallas Area Police Officers. Journal of Occupational and Environmental Medicine. 1978;20(6):393-8.

59. Sörensen L, Smolander J, Louhevaara V, Korhonen O, Oja P. Physical Activity, Fitness and Body Composition of Finnish Police Officers: A 15-year Follow-up Study. Occupational Medicine. 2000;50(1):3-10.

60. Duque I, Parra JH, Duvallet A. Maximal aerobic power in patients with chronic low back pain: a comparison with healthy subjects. European spine journal : official publication of the European Spine Society, the European Spinal Deformity Society, and the European Section of the Cervical Spine Research Society. 2011;20(1):87-93.

61. Leischik R, Spelsberg N. Endurance sport and "cardiac injury": a prospective study of recreational ironman athletes. International journal of environmental research and public health. 2014;11(9):9082-100.

62. Spitler D, Jones G, Hawkins J, Dudka L. Body composition and physiological characteristics of law enforcement officers. British journal of sports medicine. 1987;21(4):154-7.

63. Lentz L, Randall JR, Guptill CA, Gross DP, Senthilselvan A, Voaklander D. The Association Between Fitness Test Scores and Musculoskeletal Injury in Police Officers. International journal of environmental research and public health. 2019;16(23):4667. 